Article

\title{
Pastoralists' Herding Strategies and Camp Selection in the Local Commons-A Case Study of Pastoral Societies in Mongolia
}

\author{
Chifumi Ono * and Mamoru Ishikawa \\ Graduate School of Environmental Science, Hokkaido University, Hokkaido 060-0808, Japan; \\ mishi@ees.hokudai.ac.jp \\ * Correspondence: chifumi.ono@ees.hokudai.ac.jp; Tel.: +81-011-716-2111
}

Received: 21 October 2020; Accepted: 3 December 2020; Published: 5 December 2020

\begin{abstract}
Local commons are underutilized in resource management models, thus limiting the effectiveness of the commons concept. This study examined the actual situation of the local commons in Altanbulag soum, a suburb of Ulaanbaatar City, Mongolia, where land degradation is a concern, using the case study method. Interviews using semi-structured questionnaires were conducted with pastoralists. It investigated land use and pastoralists' relationships to open-access summer pastures, summer camp selection, grazing practice, and acceptance of migrants. The study concludes that herders in Altanbulag select their summer camp locations considering four elements: attachment to the place, territorial bonding, convenient environment, and winter camp safety. We also defined four types of herding strategies that identify the positive and negative aspects of local commons. The study suggests a potential gap between the community-based resource management promoted by international donors and the actual practices around local commons. It also highlights the need for further research into assessing local commons.
\end{abstract}

Keywords: local commons; herding strategy; camp selection; Mongolia

\section{Introduction}

\subsection{Commons Theory and Natural Resource Management}

In the field of natural resource management, the concept of "the commons" has been examined using various methods; however, as research has deepened, the concept has become less clear. Widely known through Garrett Hardin's article, "The Tragedy of the Commons" [1], the concept is today used in an abstract and universal sense to denote "a shared resource by a group of people" [2]. The term "commons" originally represented "resources and management systems that are customarily used by local people" in medieval England and Wales [3].

Hardin [1] imagined a tragic scenario in which resources other than those under state or private management would eventually perish: "In the pastures that belong to everyone, pastoralists with rational economic thinking increase the number of animals they keep for profit, and the pastureland eventually deteriorates and collapses due to overgrazing" [1]. While he envisioned the commons as a space open to all and free for grazing, these spaces were, in fact, not available to just anyone.

Local commons in medieval England and Wales did not grant the right to use open access resources indiscriminately, but rather it was only granted the right only to those with clear membership of the user group; there were also restrictions on the number of grazing animals allowed [3]. The commons were governed by community customs, that were ambiguous and informal but sufficiently self-managed [4-6]. In other words, the original commons represented a social system that had the potential for sustainability, as it considered the quantity of resources used. 
Since the late 1970s, economic anthropologists and human ecologists have endeavored to understand the characteristics of the commons, and have discovered several communities where local commons are customarily used as the local resource management systems [7-10]. Elinor Ostrom, who won the Nobel Prize in Economics, is famous for her work based on cases from around the world that refute the concept of "The Tragedy of the Commons." According to Ostrom, co-management of commons by local communities is possible using formal and informal institutions [11]. Under the right system, rule violations are mutually monitored in the daily utilization of resources and can be flexibly adjusted according to the status of the resources [12].

The commons theory is used as a community-based natural resources management (CBNRM) strategy in resource management policies for developing countries, and is supported by international institutions, such as the World Bank. The World Bank and the Swiss Agency for Development and Cooperation have been actively involved in using a CBNRM strategy to grant land rights to "user groups in, for example, Mongolia." Ostrom and Schlager [13] summarize the advantages of CBNRM over nationalization and privatization: with CBNRM, ownership, usage rights, and management systems are implemented, monitored, and improved by the users themselves, allowing the information on resources and the effectiveness of management to be accumulated among these users. Based on that accumulated information, management systems can be adapted to cultural environments that include people's beliefs and their views on nature.

However, it has been noted that clarifying usage rights can pose a problem if shared resource management is customarily performed where rights relationships are unclear [14,15]. It has also been reported that the success or failure of a CBNRM project depends on incorporating the cultural and organizational background of the local people into the system $[16,17]$. There is some literature that analyzes a few successful projects. Two case studies of successful CBNRM were initiated by local communities with strong attachments to their local environments [18]. Most CBNRM projects have focused on environmental protection and improving the standard of living, and therefore, the environment is livable for the local people has often been overlooked. The simplest model for analyzing a living environment is an index system that is hierarchically structured, with the residential environment at the top [19]. These indicators are often used in urban planning to achieve the coexistence of urban (convenient and artificial) and rural (inconvenient and natural) ways of life, and are used to understand the living environment of the inhabitants. Prior studies [19-21] have proposed the establishment of an environmental index that involves the living environment comprising (i) surrounding environments, (ii) human environment, and (iii) social accessibility, which is, an index that encompasses both attachment and territorial ties. This index allows us to understand what residents prioritize in their living environment. In addition, the criteria for selecting a living environment in which one would like to live for a long time are intertwined with various factors, such as occupation, family relationships, and values, hence, it is necessary to consider multiple aspects of the environment [22]. As a starting point, understanding the basic structure of the residential choice behavior of the local people is key to the success of CBNRM policies and projects.

Thus far, resource management research has sought to understand models of commons without looking at local commons, and therefore, has not fully explored their capability and effectiveness. Thus, CBNRM policies and projects need to look at how local commons operate in practice rather than solely use the commons theory as a base.

\subsection{The Mongolian Context}

Using the commons theory and employing Mongolia as a case study, this study examines the situation and problems of local commons in pastoral societies. Mongolian pastoralists have traditionally dispersed the environmental impact of their land use through migration, developing traditional ecological knowledge of mitigating natural disasters, and engaging in rangeland living for thousands of years [23]. The characteristics of suitable pastures vary according to the season, differences in vegetation, and location and type of water source. Access to wind-blocking, sunny areas in winter, 
and water sources near rivers that can provide drinking water in summer are important conditions [24]. For pastoralists, pastoral management is not possible unless a range of diverse lands are available. In addition, land rights are ambiguous due to the wide use of pastureland, and resource utilization is highly flexible [25]. Moreover, there is present a reciprocity norm that forms the basis of traditional livestock utilization in Mongolia [26]. This reciprocity norm enables resource users to enjoy mobility and flexible utilization. The reciprocity principle works on a wide range of rights, labor, and goods, and facilitates individuals' introduction to local leaders and politicians. The expectation of these rewarding exchanges has led to flexibility in resource utilization for outsiders, who have migrated from other areas, allowing them to make opportunistic moves. The conventional mechanism of the pastoral system, which allows for mobility, flexibility, diversity, and reciprocity, prevents the deterioration of the Mongolian pastureland. This land is characterized by low rainfall and rapid weather fluctuations, nevertheless, it has supported the livelihoods of pastoralists for many generations $[27,28]$.

The local commons comprise both the customs established by Mongolian pastoral societies and the natural resources of interest. However, natural resources are not the only resources in a pastoral society. The people and the connections between them in the community are also considered resources. Cooperative behavior is likely in areas where social capital is characterized by networks based on reciprocity and where connections are accumulated [29-31]. In such networks, it is possible that there are persons from other areas who have multiple residences, as well as new residents to the area. In this study, the local commons are defined as the natural resources that form the basis for the livelihood of the local community and the interactions between the people who communally use them, as well as their utilization systems. The utilization system includes common understanding and ambiguous norms implicitly understood by people in the local community.

The transition of Mongolia from a socialist to a market economy in the 1990s had a major impact on the use of its rangeland. During the socialist period before 1990, the negdel (agricultural association) was responsible for the infrastructure development and the market access necessary for pastoralists [32,33]. However, after the transition to a market economy, the negdels were dismantled and their functions left unfulfilled [32,34]. Therefore, settlements began concentrating near markets and roads since it was easier to access public services, such as medical care and education [25].

As a result, pastoral strategies have diversified to respond to socio-economic changes. M.E. Fernandez-Gimenez, in her field research in Bayankhongor province, noted the concentration of livestock near roads and towns and reduced mobility. She also cites the absence of official restrictions on land use and the weakening of customary rights as the backdrop to this situation [25]. Another paper also points to the trend of wealthy pastoralists tending livestock grazing for absentee herd-owners living in settled areas [25].

The suburbs of the capital Ulaanbaatar have been particularly vulnerable to these influences. In Mongolia, pastures are theoretically open-access during summer and autumn, when grass grows best; however, during winter and spring, it is customary to restrict the use of these pastures to households other than those who have used them for a long time [35]. However, in the suburbs of Ulaanbaatar, pastoralists from other areas have been known to use the winter and spring pastures without permission [25]. To resolve such conflicts, the Land Law includes provisions for establishing possession rights (the right to exclusive use of the land for a certain period) of the winter and spring camps according to custom. However, rich herders have become increasingly reluctant to leave their summer camps, even after winter or spring, to protect their investments in the winter and spring camps and the surrounding pastures [36].

In response, CBNRM groups began forming in Mongolia during the late 1990s to address, through different projects, the declining pasture conditions and rising rural poverty. According to a study focused on how CBNRM projects operate, members of CBNRM groups are more proactive in addressing resource management issues and use more traditional and innovative rangeland management practices-including formal rangeland monitoring - than non-members [37,38]. In addition, the social capital index of the herder groups is rising [39]. However, in one study, herders were using the CBNRM 
project not for resource management but for financial support directly related to their livelihood. When the project ended, the herder groups ceased to engage in CBNRM activities [40]. Thus, the CBNRM in Mongolia will remain problematic. It is a problem of adapting CBNRM to Mongolia's unique situation. Of particular interest is the relationship between the characteristics of resource use of pastoralists in Mongolia and the CBNRM design [15]. Ostrom [11] cites defining the range of users to be granted rights and drawing boundaries as the foremost principles of suitability management. On the other hand, Mongolian mobile pastoralists have adopted flexible forms of resource use, and it is also acknowledged that the boundaries between both the scope of the resource and the scope of the collective members with access rights are blurred [26]. Therefore, these flexible forms of use are inconsistent with the implementation of CBNRM, which reflects Ostrom's design principles. This is a challenge to the introduction of CBNRM into Mongolian pastoral societies.

In this paper, we examine how pastoralists make decisions about land use, seasonal camp selection, and daily grazing sites in the rangeland suburbs of Ulaanbaatar. We consider what pastoral strategies are in place and discuss the reality of the local commons. Registration is not required for the locals in summer and autumn pastures. Pastoralists can change summer and fall camp locations relatively freely as they move to seek grass to fatten their livestock. On the other hand, bugh (rural sub-district) approval and registration is necessary to obtain possession rights for winter and spring camps. In addition, the floors of livestock shelters are made using layers of livestock manure for warmth and hence, cannot be moved; consequently, the location of a camp in winter or spring rarely fluctuates. Therefore, summer grassland use is susceptible to marketization due to the higher degree of freedom of camp movement. Thus, this study focuses on summer pastureland use, to better understand the conditions of the local commons.

\section{Study Area}

\subsection{Area Description}

Mongolia is a landlocked country situated in East Asia and bordered by China and Russia. Most of the country is steppe grassland, falling into three major ecological zones: mountain steppe, steppe, and desert steppe. Roughly one-fifth of Mongolians are pastoralists. The study area was the Altanbulag soum (rural district) in the Tuv aimag (province) in central Mongolia (Figure 1). Altanbulag soum is located approximately $50 \mathrm{~km}$ southwest of Ulaanbaatar, where a variety of land uses and land use actors are found. The area, divided by the Tuul river, has a combination of climate zones. The north of the river is mostly forest steppe and steppe, while the south is steppe and the Gobi Desert.

Adapted from Tshukihara [41] and Humphrey and David [27], three main categories of land use actors were identified for this study: permanent residents (farmers, soum residents, and wildlife park wardens), semi-pastoralists, and mobile pastoralists (including migrant pastoralists). This study does not consider permanent residents. Semi-pastoralists often host foreign tourists during the summer to supplement their income. Mobile pastoralists earn their livelihood solely from pastoral income. Migrant pastoralists in this study are defined as those who arrived in the Altanbulag soum after its transition to a market economy.

\subsection{Seasonal Migration}

Nomadic pastoralism is the movement of livestock and herders according to seasonal and ecological conditions. Seasonal movement patterns have been largely unchanged since the shift to a market economy; however, distances traveled are shorter and there are fewer camps [42]. Mongolian herders currently move two or three times per year and for shorter distances than during the negdel period due to water shortages and lack of clear instructions from the head of the negdel regarding when and where to move [42]. These herders cannot flexibly migrate unless there is an emergency, such as a natural disaster; the range of migration is restricted to within the soum or bugh by the soum governor where the pastoralists are registered as residents [43]. 


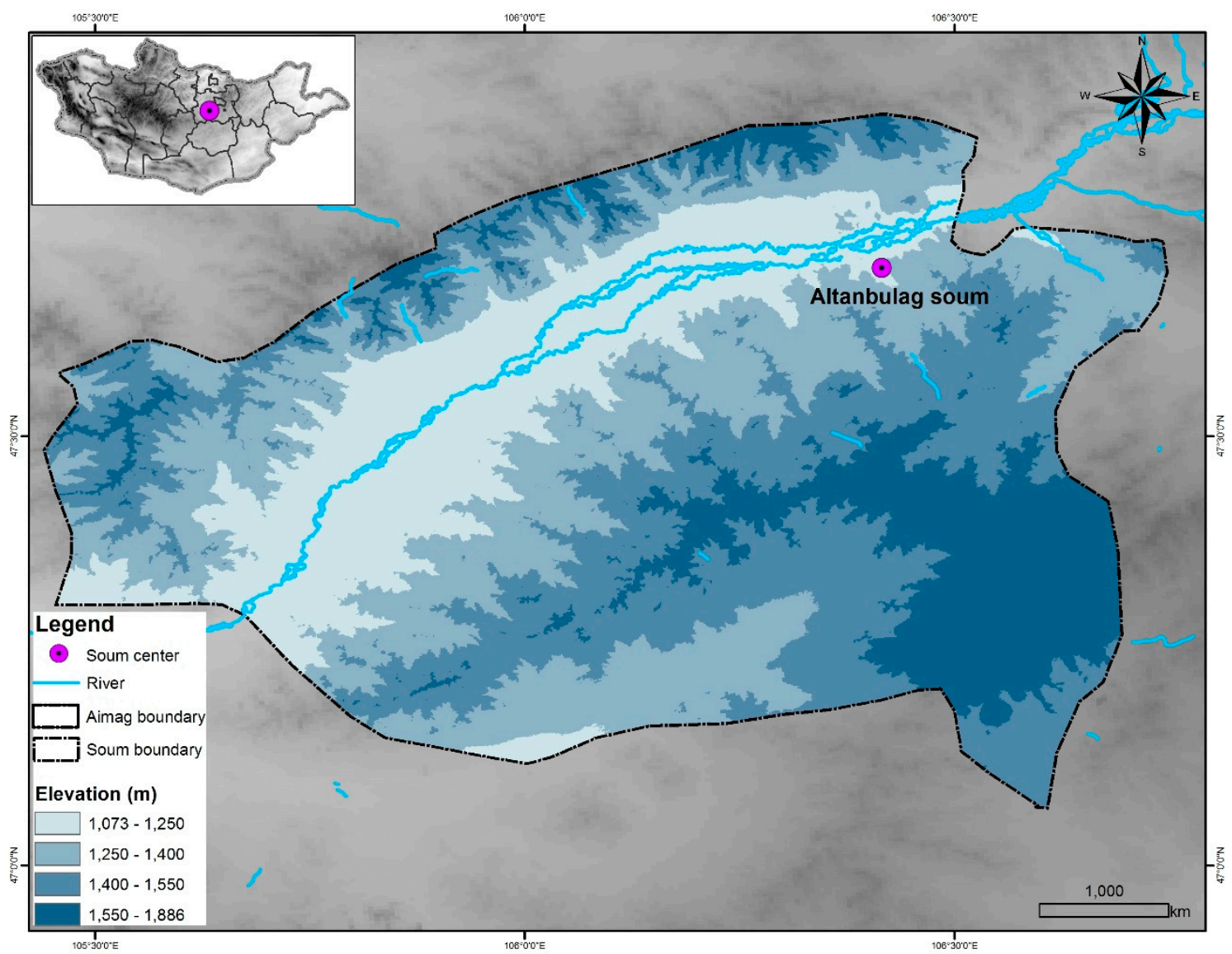

Figure 1. Study area, elevation map of the Altanbulag soum.

Herders' seasonal movement patterns generally depend on geography; thus, it is strategically important for them to access a combination of mountainous areas, foothills, and lowland valleys. Winter and spring camps are in the foothills or on the southern slopes of mountains, which are protected from strong winds. Summer and autumn camps are located along the river or lowland valleys to ensure access to water.

As previously mentioned, the summer and fall pastures used during grass-growing season are open access in principle. Regarding the winter and spring camps and nearby pastures, custom restricts use by households other than those that have historically used these lands [35]. In accordance with such customs, the Land Law in Mongolia includes provisions on pastureland and its proper utilization and protection. According to article 52.1 of the Land Law, the soum and duureg (municipal district) assembly consider the characteristics of the area, such as proper utilization, traditions of pasture use, protection, and restoration, and establish land management plans with fundamental land use patterns (winter, spring, summer, and autumn camps and reserve pastureland). The summer and autumn camps and reserve pasturelands are assigned to the bugh or khot-ail (the basic herding camp of several cooperating households) and are used as common areas (Article 52.2). Considering herders' opinions and yearly pasture growth, certain periods are scheduled to permit livestock entry into the spring and winter camps, thereby allowing degraded pastures to recover (Article 52.2). The Land Law, thus, includes provisions for establishing possession rights of winter and spring camps according to prevailing customs. 


\section{Materials and Methods}

A case study was used as the research methodology to investigate how herders carry out herding strategies. This method was preferred because it allows for the use of various methods to obtain and analyze data.

To understand the current state of land use during the summer, we conducted a field survey of where the summer camps are established, collecting their location information with GPS, and conducting household surveys. We traveled on paved and unpaved roads to find the summer camps, and collected their location data (except for empty homes). Our survey of herding households covered summer camp location, household composition, number of livestock, livestock composition, and land use behavior. It was conducted in July $2011(n=24)$, August $2012(n=29)$, and August $2015(n=42)$. We obtained 82 and 13 data points regarding location and households from mobile and semi-pastoralists, respectively. Herders were asked closed questions regarding their views on summer camp decisions. We gathered 95 data points for summer camp locations.

Additionally, we used semi-structured questionnaires for face-to-face interviews to clarify herder customs and relationships between herders. Both open and closed questions were presented to herders: (i) What are the reasons for choosing summer camps? (ii) Who decides on the management of summer camps and grazing pastures? and (iii) Would you accept migrants if they came into the grazing area? Herders were asked open questions about their views on their relationships with other herders. Data were collected in August 2015 along with the location data. We obtained 42 completed questionnaires from mobile pastoralists.

Prior to face-to-face interviews, all interviewees were informed of the purposes of the research and how the results would be used. All interviewees gave their consent to participate. Data sharing is not applicable to this article as no large publicly available datasets were generated or analyzed during this study.

\section{Results}

\subsection{Location of Summer Camps}

An administrative unit called a bugh describes the range of seasonal movement. The Altanbulag soum has four bughs. Fixed locations in the winter and spring pastures are approved by the head of the bugh, and unless a natural disaster occurs—such as a dzud (extreme winter weather) - it is not possible to systematically graze in other places. However, the location of campsites is unrestricted in the summer and autumn camps and herders need only register the location of the campsite with the head of the bugh. Most semi-pastoralists locate their camps in rangelands near the soum center, whereas mobile pastoralists locate their camps along the river or in the lowland valley. Figure 2 shows the spatial distribution of the summer camps.

\subsection{Source of Camp Selection in the Altanbulag Soum}

Semi-pastoralists typically have up to a dozen livestock while mobile pastoralists have a few hundred livestock (Table 1). Some semi-pastoralist family members hold regular jobs in the soum center. In summer and autumn, a khot-ail (consisting of 2-10 households) is constructed in a pasture several kilometers away from the soum center, and livestock labor is shared among the households (Figure 2). In winter and spring, herders manage their livestock by leaving them with relatives or friends where they are housed and fed in a shelter on the rangeland to provide warmth. Herders with summer camps near the soum center tend to focus on the following comprehensive social infrastructure, which is close to the workplace and convenient for receiving foreign tourists. This is how they describe their camp selection: 
Table 1. Number of livestock owned by mobile pastoralists $(n=82)$ and semi-pastoralists $(n=13)$.

\begin{tabular}{ccccccc}
\hline & \multicolumn{3}{c}{ Mobile Pastoralists } & \multicolumn{3}{c}{ Semi-Pastoralists } \\
\hline & Min & Max & Mean & Min & Max & Mean \\
Sheep & 10 & 2000 & $274.9(200)$ & 0 & 200 & $53.25(29.5)$ \\
Goat & 0 & 700 & $221.0(200)$ & 0 & 100 & $41.25(30)$ \\
Cattle & 0 & 500 & $46.7(27.5)$ & 0 & 24 & $11.4(11.5)$ \\
Horse & 0 & 600 & $66.9(40)$ & 0 & 70 & $30.5(27.5)$ \\
Camel & 0 & 90 & $1.1(0)$ & 0 & 0 & $0(0)$ \\
\hline
\end{tabular}

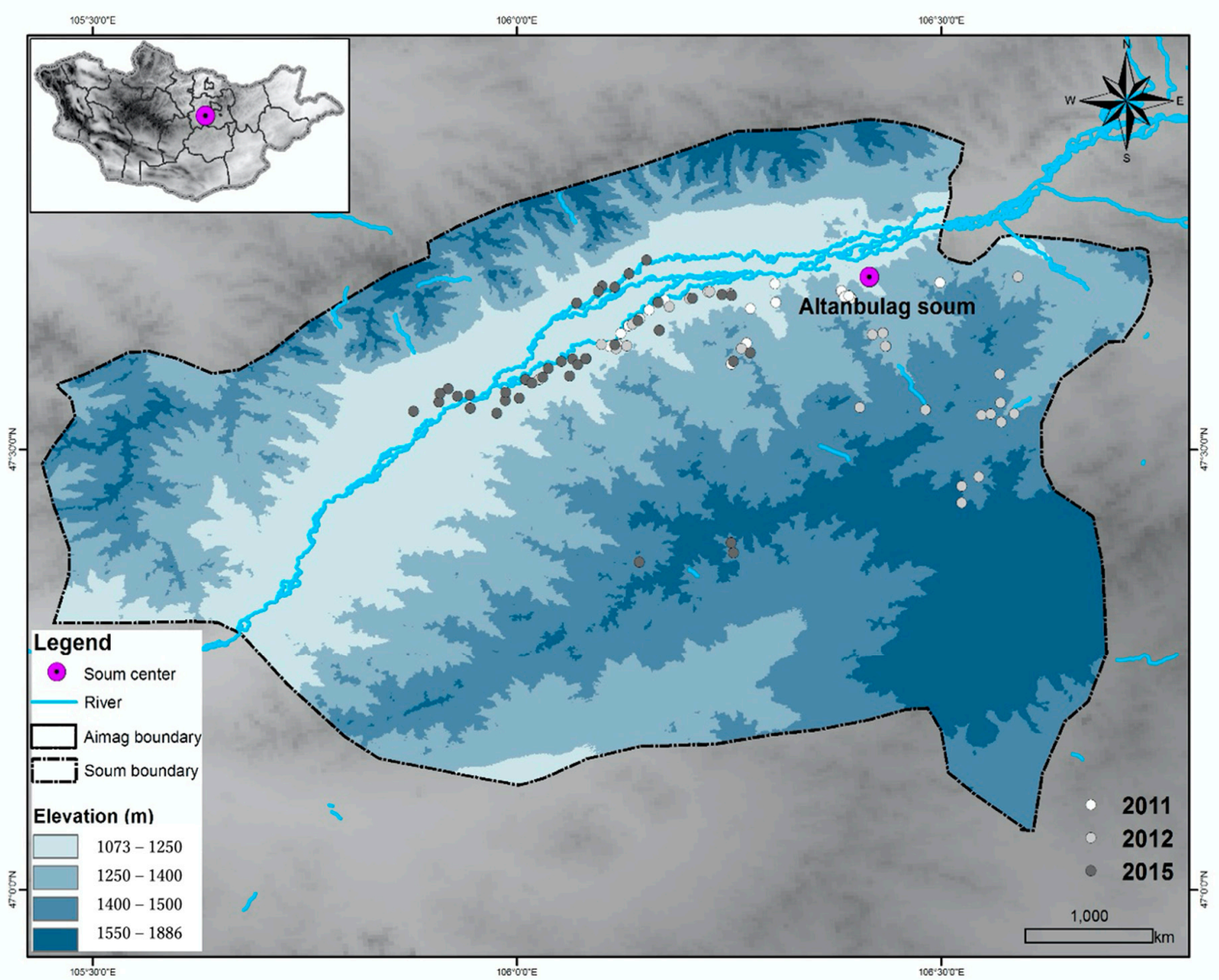

Figure 2. Spatial distribution of the summer camps in the Altanbulag soum $(n=95)$.

My wife is a teacher, so it is good to go to work near the center. Besides, it is convenient for my mother to be close to the hospital (Herder, Place 15/95).

In this khot-ail, the number of livestock is small, so we are letting them graze together. It's convenient because I only have a few cows right now and I can go straight to the soum center to sell the milk from the cows in the morning and evening. If we're away from the city, we can't go to sell milk and must process it into cheese (Herder, Place 13/95).

It's close to Ulaanbaatar. Sometimes, I get a job serving meals and giving horseback rides to foreign tourists who come on a day trip. Since they arrive on a large bus, I cannot accept the group even if relatives assist because of insufficient manpower. However, if the khot-ails around this area gather, there will be more than ten households, so it would be a good source of extra income if everyone cooperates. Mostly, the same families gather every year to go to the summer camp around here (Herder, Place 16/95).

Most mobile pastoralists were living along the Tuul river with abundant water, grass, and open space. However, there were several herders who preferred the lowland valley on the mountainside. 
When asked why they chose this place, most herders answered that they have inhabited and utilized this land for many years; the second most common answer regarded the natural environment surrounding the camp:

There are many places near the river, such as wetlands, and the amount of grass and water are plentiful, which make livestock happy. In summer, when I want to provide water to lots of livestock, I can just take them to the river, which makes watering livestock very easy (Herder, Place 10/95).

There are many "Mongol Uvs" (Grass; Stipa krylovii) around this area that the livestock like eating. Watering livestock using wells is hard work, but the mountainside is good because I can feed the livestock lots of good grass in a large area (Herder, Place 36/95).

In addition, there were answers related to monitoring the winter/spring camp and to preferring places where livestock became accustomed to grazing:

I am watching the winter camp from here and if livestock come in, I must drive them out. If another herder's livestock eat grass during the summer, I will have trouble during the winter. I really want to spend the summer by the river, but I can't help it (Herder, Place 23/95).

Since the number of pastoralists on the mountain side is small and the grassland is in good condition compared to the river side, I once moved to the mountain side with my livestock, but the livestock did not get used to the pasture and immediately returned to the river (Herder, Place 11/95).

I wanted to feed the livestock a lot of water, so I took them near the river, but the livestock hate it there because there are so many mosquitoes, so they returned to their original pasture. We follow the livestock and decide where to live accordingly (Herder, Place 38/95).

The results of the open question revealed that most mobile pastoralists established summer camps in places they were used to living for many years. In response to this, we inquired about the factors for selecting summer and winter camps (Table 2 and Figure 3). The most common reason for choosing a summer camp was "used area during socialist period (before 1990)" (67.5\%), followed by "used area since parents' generation" (22.5\%). According to the minority of herders who answered "first come, first served," the reason was that "the summer pasture is not owned by anyone, we move to find a place with good grass conditions" (Herder, Place 2 and 11/42). The four herders who responded were neither migrants nor inexperienced. Regarding the winter camp, they acquired rights in a manner that complied with the Land Law, such as through inheritance from parents, rights obtained by registering themselves, or shared use.

Summer camp and pasture

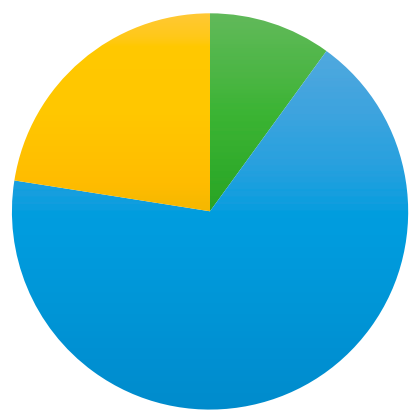

Winter camp and pasture

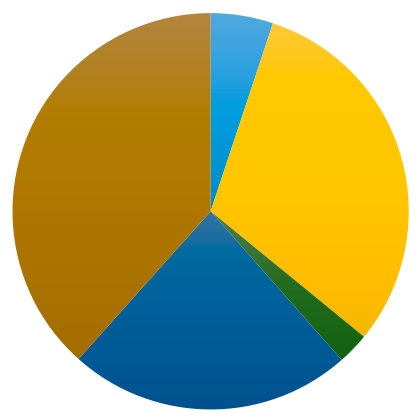

\footnotetext{
First come, first served

Used area from socialist period

Used area from parents' generation or inherited rights from parents

Spouse inherited rights

Requested distant kin or friends to gain access rights

- Claimed access rights via soum residence
}

Figure 3. Source of camp selection and pasture in the Altanbulag soum. Data source: FernándezGiménez [36]. 
Table 2. Source of camp selection and pasture in the Altanbulag soum. Data source: Fernández-Giménez [36].

\begin{tabular}{ccccc}
\hline & \multicolumn{2}{c}{ Summer Camp and Pasture } & \multicolumn{2}{c}{ Winter Camp and Pasture } \\
\hline & Number & \% Within Category & Number & \% Within Category \\
\hline First come, first served & 4 & 10 & - & - \\
Used area from socialist period & 27 & 67.5 & 2 & 5.1 \\
Used area from parents' generation or inherited rights from parents & 9 & 22.5 & 12 & 30.8 \\
Spouse inherited rights & - & - & 1 & 2.6 \\
Requested distant kin or friends to gain access rights & - & - & 9 & 23.1 \\
Claimed access rights via soum residence & - & - & 15 & 38.4 \\
Total & 40 & 100 & 39 & 100 \\
\hline
\end{tabular}

\subsection{Annual Change of Summer Camp Location}

The annual change in summer camp location has a relatively large selection range that depends on yearly weather conditions. Six households were selected from the mobile pastoralists (Figure 2) surveyed in 2011, and a follow-up survey was conducted in 2012 and 2015 in the summer camp location. Figure 4 shows an example of changes in the summer camp location of six herders. Data are missing for households who were not home at the time of the survey and details about their whereabouts could not be determined. There were no significant differences among the meteorological conditions of 2011-2012, and 2015.

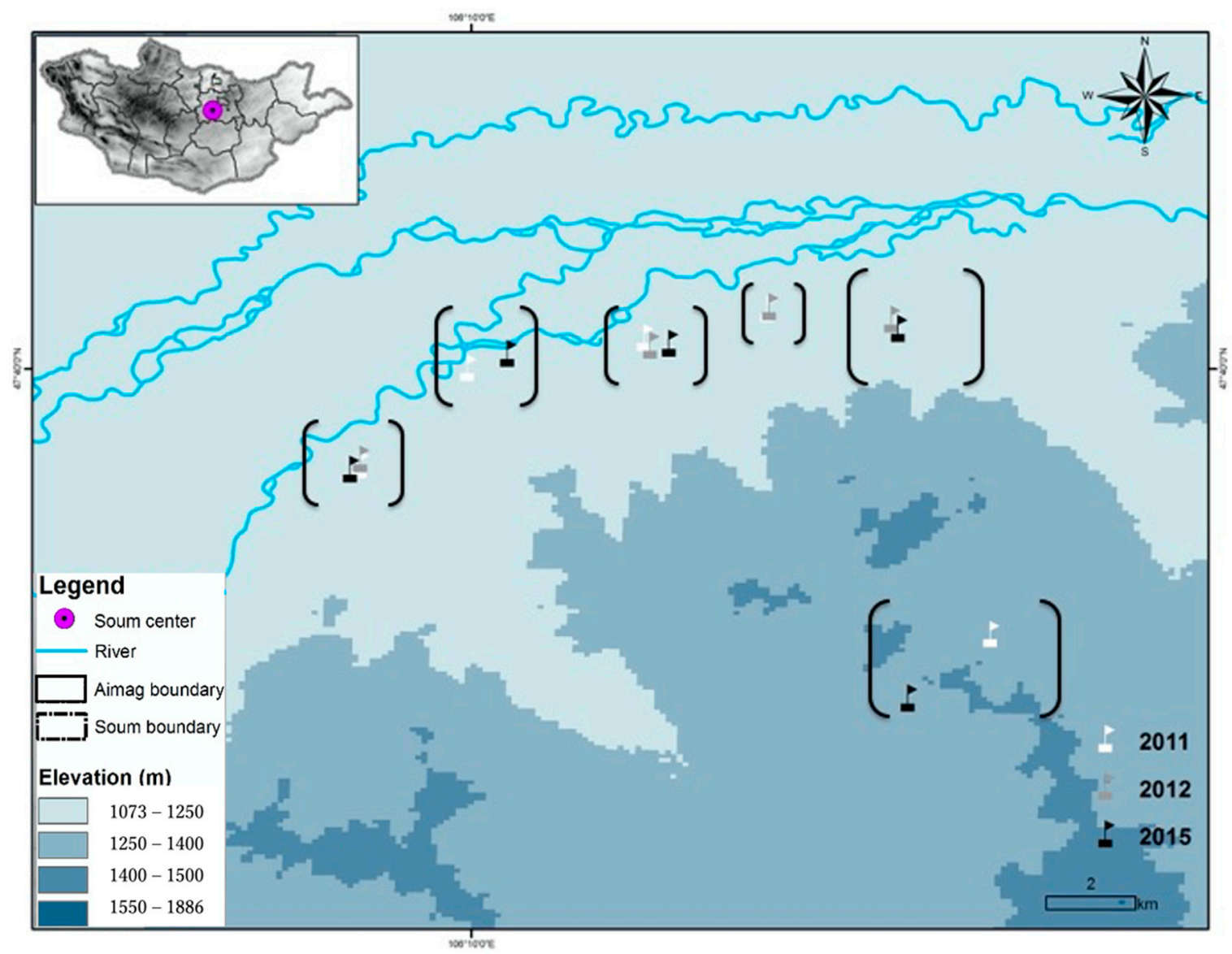

Figure 4. Annual change in the summer camp location of six households.

The location of the summer camp generally coincides with the results of the three-year survey, and there is a tendency for the summer camp to be established within a range of several hundred meters to several kilometers from what is recognized as "the same place." Regarding the selection of summer camps in poor pasture conditions, one opinion was that "it may delay the migration time from spring camps when grass growth in summer pasture is poor" (Herder, Place 32/95) and "basically, the location 
would not change. It moves only three times a year, but when the grass is scarcer, it may increase to four times" (Herder, Place 33/95). In other words, for the Altanbulag herders, seasonal migration routes are patterned, although there are differences among households in terms of migration time.

\subsection{Herding Practices and Decision Making in Summer}

We conducted a survey of mobile pastoralists to investigate the relationships between herders when selecting a summer camp and grazing practices. First, we asked whom the herders consult when choosing a summer camp (Table 3 and Figure 5). Most herders select a summer camp by consulting their family. Next, we listed whom the herders consulted when selecting their daily/weekly/seasonal grazing routes and grazing pastures (Table 3 and Figure 5). Similar to the selection of summer camps, approximately half of the pastoralists selected grazing routes and grazing pastures after discussing them with their families. In addition, only the head of the household determined the daily grazing path and weekly grazing area, and his kin (close relatives) were slightly more involved in selecting the grazing pasture. Decisions about seasonal events may feel more important than decisions about daily grazing practices:

Table 3. Adviser consulted when selecting the summer camp, grazing path, area, and pasture.

\begin{tabular}{ccccccccc}
\hline & $\begin{array}{c}\text { Choose Summer } \\
\text { Camp }\end{array}$ & $\begin{array}{c}\text { Choose Route of } \\
\text { Grazing Path (Daily) }\end{array}$ & \multicolumn{2}{c}{$\begin{array}{c}\text { Choose Grazing } \\
\text { Area (Weekly) }\end{array}$} & $\begin{array}{c}\text { Choose Seasonal } \\
\text { Pasture (Seasonally) }\end{array}$ \\
\hline & Number & $\begin{array}{c}\text { \% Within } \\
\text { Category }\end{array}$ & Number & $\begin{array}{c}\text { \% Within } \\
\text { Category }\end{array}$ & Number & $\begin{array}{c}\text { \% Within } \\
\text { Category }\end{array}$ & $\begin{array}{c}\text { Number } \\
\text { \% Within } \\
\text { Category }\end{array}$ \\
\hline Household head & 5 & 12.5 & 12 & 30 & 12 & 30 & 4 & 10 \\
With family & 25 & 62.5 & 21 & 52.5 & 19 & 47.5 & 21 & 52.5 \\
With kin (close relatives) & 5 & 12.5 & 1 & 2.5 & 1 & 2.5 & 7 & 17.5 \\
With neighborhood & 0 & 0 & 1 & 2.5 & 2 & 5 & 2 \\
With Khot-ail & 5 & 12.5 & 2 & 5 & 2 & 5 & 1 \\
With another group & 0 & 0 & 0 & 0 & 1 & 2.5 & 1 \\
Others & 0 & 0 & 3 & 7.5 & 3 & 7.5 & 4 & 2.5 \\
Total & 40 & 100 & 40 & 100 & 40 & 100 & 40 \\
\hline
\end{tabular}

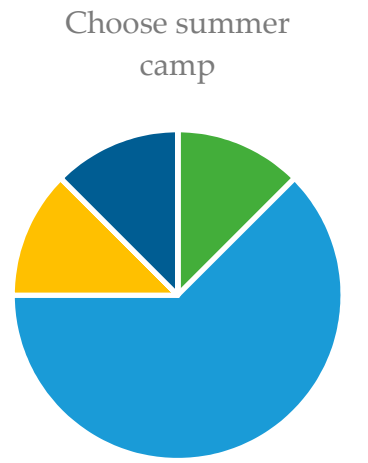

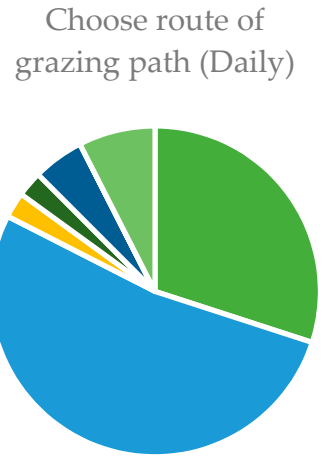

- Household head

With neighborhood

Others

\section{Choose grazing area \\ (Weekly)}

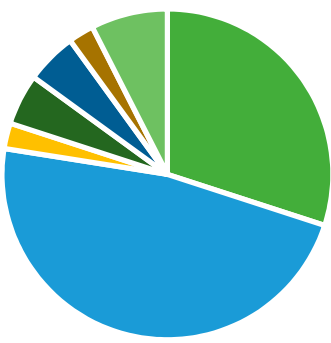

With family

With Khot-ail
Choose seasonal pasture (Seasonally)

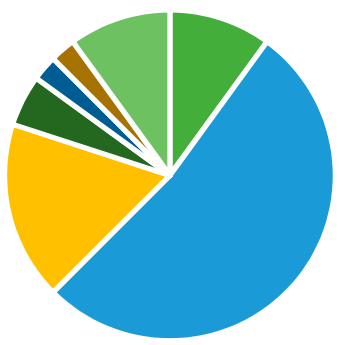

With kin (close relatives)

With another group

Figure 5. Adviser consulted when selecting the summer camp, grazing path, area, and pasture.

During the summer, we do not accompany the livestock all day long...the livestock remember the location because they have been grazing at the same time and the same location for many years. So, they will return at the set time and I just guide them in the direction I want them to go when they start grazing (Herder, Place 11/42).

Summer grass grows well, so I can feed the livestock anywhere. So, I never consult anybody about grazing (Herder, Place 18/42). 
I use the same place every year and we know everyone there. It's our own place and is not used without permission (Herder, Place 26/42).

In summer there is no problem with grazing areas, but in the years when there is little grass, the migration time is adjusted. In such cases, I consult with kin and friends (Herder, Place 7/42).

\subsection{Migrant Camp Selection}

We examined the relationships among herders focusing on migrant pastoralists and pastoralists. First, we asked whether migrants would be accepted if they came into a nearby grazing area. The migrants were classified as kin, friends, or unknown people, and the results are shown in Table 4 and Figure 6. Approximately half of the pastoralists answered that they would not accept the migrants if possible, regardless of kinship status. The most common reason extended was that "already there are so many pastoralists that there is no surplus on the pasture to accept migrants" (Herder, Place 21/42) or "there was no space when other people came before" (Herder, Place 36/42). However, a few pastoralists responded that they would eventually accept or help their kin in trouble.

Table 4. Proportion of migrant acceptability.

\begin{tabular}{ccccccc}
\hline & & Accept Positively & Accept Slightly & Hard to Accept & Unacceptable & Total \\
\hline \multirow{2}{*}{ Kin, friends } & Number & 3 & 7 & 25 & 39 & 4 \\
& \% Within category & 7.7 & 17.9 & 64.1 & 10.3 & 100 \\
\hline \multirow{2}{*}{ Unknown people } & Number & 0 & 4 & 17 & 18 & 39 \\
& \% Within category & 0 & 10.3 & 43.6 & 46.2 & 100 \\
\hline
\end{tabular}

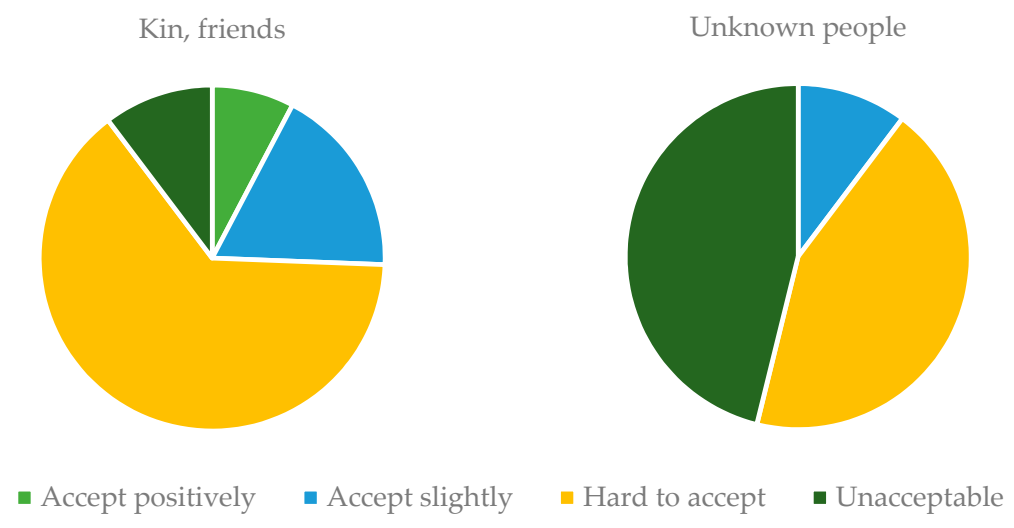

Figure 6. Proportion of migrant acceptability.

Next, we conducted informal follow-up interviews with migrant pastoralists and obtained some examples of how they interacted with pastoralists when they migrated:

Last year, I came from Hovd Province ... I had applied for immigration before coming. I was acquainted with the bugh's head, so I requested the use of the summer camp near the river and was told to get permission from the surrounding herders ... When I went to another soum, I was sometimes left out (Herder, Place 51/95).

I moved from Dondgovi Province 10 years ago ... I want to be near a riverside with lots of grass because there are only private wells around here. But there is no space that can be used because there are many herders ... To the east of Altanbulag there are many migrants like us (Herder, Place 40/95).

I went to Ulaanbaatar once from Bayankhongor Province. I came here four years ago because I couldn't settle into city life ... At first, I was looking for a place on the south side of the river. It's close to the soum center. However, I came to the north side of the river because the surrounding herders opposed me. Here, I was accepted (Herder, Place 32/42).

The locations of migrants' camps are shown in Figure 7. Many migrants established summer camps in places other than the south side of the river, which is the main area of interest for pastoralists. 


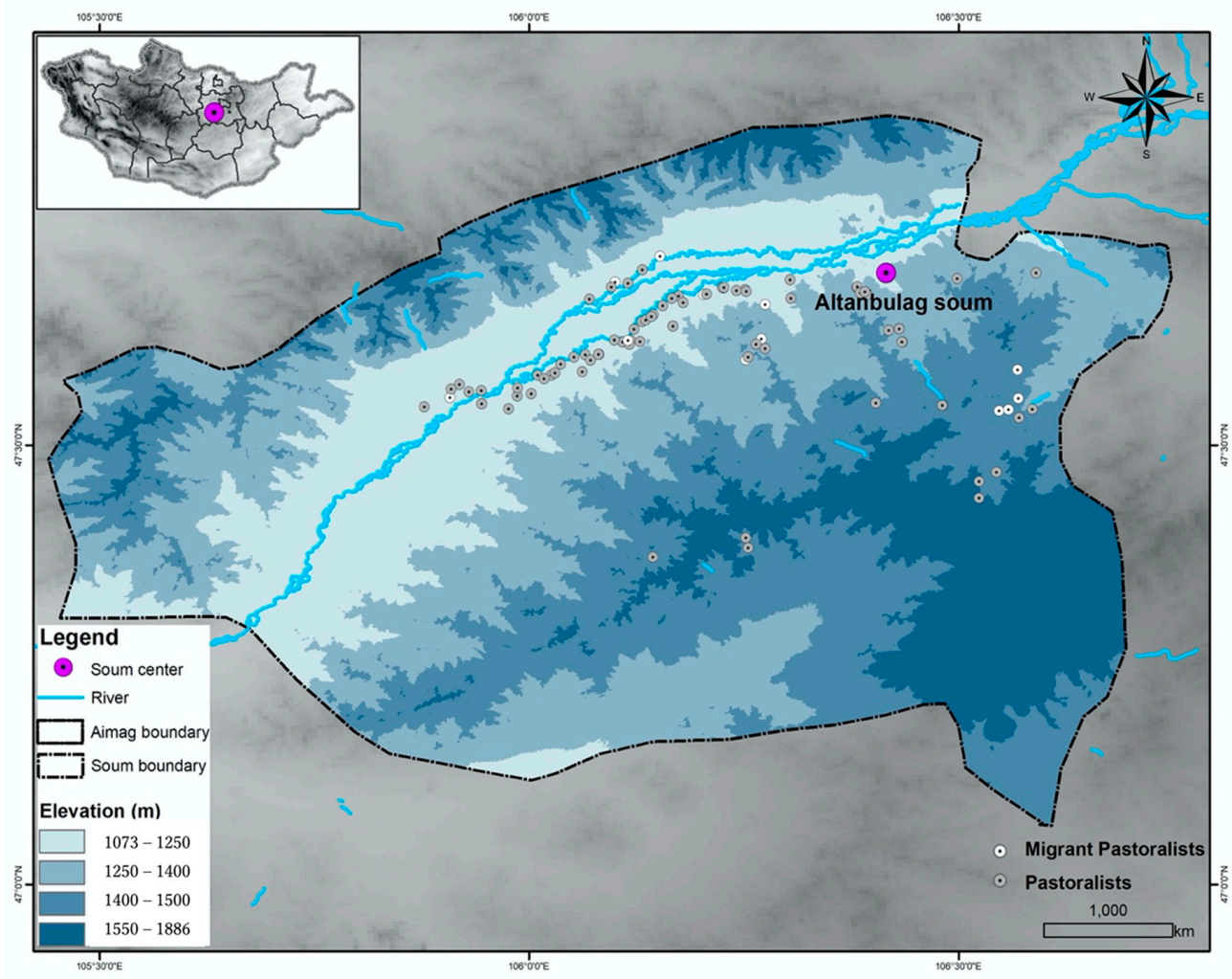

Figure 7. Camp location of migrants.

\section{Discussion}

\subsection{Determinants of Summer Camps}

Pastoralists try to use well-conditioned pastures to fatten livestock. Good pasture conditions include edible grass for livestock for several consecutive days and easy access to drinking water for both people and livestock. In addition, because the characteristics of suitable pastures change depending on the season, other important conditions, such as a sunny place in winter and a cool, well-watered place that is open on all sides in summer are also considered [44,45]. Even in the study area, it was revealed that summer camps are distributed along rivers and lowlands (Figure 2). The ecological and geographical knowledge of campsite selections that pastoralists have accumulated over many years has been inherited by the present generation as traditional ecological knowledge for environmental adaptation.

So far, campsite selection has been discussed only from the ecological and geographical perspectives. However, based on the responses to the open question, it became clear that pastoralists are conscious of various environmental factors other than the ecological/geographical environment when selecting a campsite. Therefore, we examined how pastoralists prefer to live in their summer camps based on living environmental indicators. As mentioned earlier, the environmental indicators that comprise the living environment are based on three evaluation dimensions: (i) surrounding environments, (ii) human environment, and (iii) social accessibility.

First, the surrounding environment is considered as follows. Pastoralists move with livestock in search of places that have abundant grass and water, and are cool in summer and warm in winter. Such a surrounding natural environment is the most important factor and a precondition for summer site selection. Next, as an exception, because some pastoralists monitored their winter and spring camps from their summer camp, the safety of winter camps could be cited as an environmental indicator (Section 4.2; Herder, Place 23/95). Just as some pastoralists are reluctant to leave winter and spring camps to protect them from others [36], it is suggested that, if the order of pasture use is not 
maintained in the future, there may be an increase in the number of herders who choose a territory with an emphasis on the safety of winter camps.

The next factor is human environment. In central Mongolia, when the level of precipitation is lower than usual, the amount of plant resources per unit area decreases; therefore, herders manage by increasing the distance and number of seasonal movements [44]. The summer camp has a social aspect in which the annual camp location can be easily changed according to the temperature, amount of rainfall, and plant availability based on the judgments of the herders. Nevertheless, it was revealed that most pastoralists established summer camps in places in which they were accustomed to living for many years, following the migration patterns from their parents' or grandparents' generations (Table 2). Moreover, factors, such as territorial bonding and place attachment are considered to influence determinants of summer camp selection for both herders and livestock. This is because livestock dislike unfamiliar lands and are unwilling to move to unfamiliar places to seek water and grass (Section 4.2; Herder, Place 11/95 and 38/95).

The third factor is social accessibility. The semi-pastoralists set up their summer camps near the soum center from where it is convenient to commute, receive tourists, and transport dairy products (Section 4.2; Herder, Place 13/95, 15/95, and 16/95). The fact that the mobile pastoralists set up their camps close to the river is also thought to be an indication of desiring convenient water resources (Table 2). Therefore, "accessibility of pastoral activity" and "accessibility of social infrastructure" are two factors that determine the selection of summer camps.

Outcomes of the survey at the Altanbulag soum correspond to the (i) surrounding environment, (ii) human/livestock environment, and (iii) convenient environment. Furthermore, six sub-items were identified to explain these categories based on the results of informal interviews and summer camp locations, and the residential environment index system in the rangeland around Ulaanbaatar was constructed as shown in Figure 8. Summer camp selection based on the ecological and geographical environment has changed to include a combination of the three above-mentioned dimensions due to the social and economic changes brought about by Mongolia's transition to the market economy.

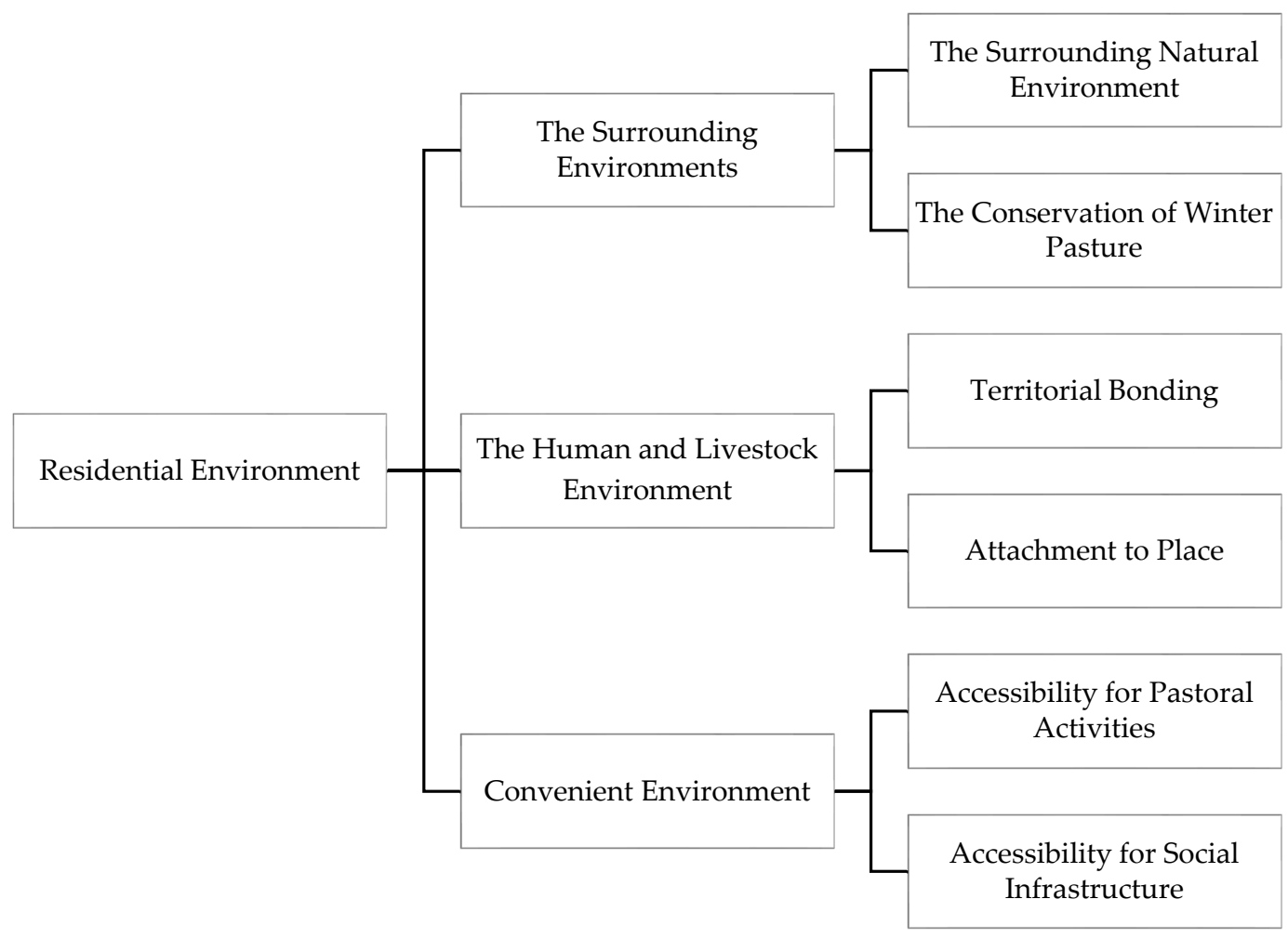

Figure 8. Residential environment index system in rural Mongolia. 


\subsection{Land Use and Herding Strategies of Pastoralists}

Next, we examined and analyzed the livelihood strategies of pastoralists from the determinants of spatial distribution of summer camps and the determinants of summer camps. Pastoralists have adopted different herding strategies for each while continuing their seasonal migration. Although strategies are freely selected, they can be classified into several types because they are limited to the knowledge and skills related to livestock, the environment, and social situations [46]. A representative example of a discussion of Mongolian pastoralist strategies is that of Sneath [45]. He sought to understand the mixed situation where some people engaged in long-distance seasonal migration while others engaged in short-distance migrations as different types of pastoral production activities, namely, yield-focused and subsistence mode. The yield-focused mode refers to when grasslands are used to obtain maximum benefit from the livestock herd as property. The subsistence mode, on the other hand, is oriented toward meeting demands within the household and cannot disregard the profits obtained from livestock sales and other sources for the purchase of goods. We consider these theories below. When categorized based on the living environment index and land use, the Altanbulag soum comprises four types of herding strategies:

"Convenient Environmentally Focused" - "Yield-focused mode" herding strategies along the river (Riverside yield-focused mode): Pastoralists who form a social sphere in the plains on the south side of the river can secure abundant water and grass, and the soum center can be easily reached by a straight road. Pastoralists from Altanbulag soum are the central figures who own many livestock and live on their pastoral income. In addition, due to high market accessibility, they receive seasonal cash income by shipping fresh milk. Weakness: There is a concern that the high density of summer campsites and livestock may degrade the pasture due to excessive use; however, the pasture is being used without the presence of any migrants.

"The Surrounding Environmentally Focused"—-"Subsistence mode" herding strategies on the mountain side (Mountain side subsistence mode): Pastoralists who live in the lowland valley in wide areas on the mountain side can secure a wide range of pastures and grasses highly preferred by livestock; however, these pastures are distant from the market and inconvenient. There are Altanbulag-born herders and migrants in this group, and they make a living solely from pastoralism. They also process milk and turn it into cheese, which supplements their income. Weakness: Using wells is more labor intensive than being close to the river.

"The Surrounding Environmentally Focused"—-Subsistence mode" herding strategies on the north side of river (North riverside subsistence mode): Pastoralists who live in the plains on the north side of the river can secure abundant water and grass, although the location is inconvenient because a river must be crossed to reach the soum center. There are Altanbulag-born herders and migrants in this group who make a living solely from pastoralism. The herders here maintain a pastoral life while placing importance on places with few summer camps and good natural environments. Dairy products are produced for household consumption rather than for sale at the market owing to the inconvenient location of the camps that are far from the soum center. When cash is needed, several livestock are sold together; the pastoralists do not rely on a regular cash income. Weakness: Inconvenient.

"Convenient Environmentally focused" - “To enjoy both cash income and commons on household basis" herding strategies near the soum center (Side job mode): Semi-pastoralists who live in a convenient plain area near the soum center maintain a regular source of income from work other than livestock herding while also raising a small number of livestock. As the suburbs surrounding the soum are not rich in water or grass, the semi-pastoralists cannot spend a lot of time on livestock management. Of the four pastoral systems, this system is characterized by management of the lowest number of livestock. Weaknesses: Lack of grazing space and time to increase the number of livestock.

Through changes in the social and natural environment, various pastoral systems and herding strategies have been created within one soum by the shared use of resources that individual herders accumulate. In other words, due to the growing relationship with the market, there has been a 
phenomenon of diversification of pastoral practice orientation in each small area or pastoralists themselves choosing areas that suit their diversified strategies.

It is important to note here that the boundaries of these strategies are ambiguous and fluid, and that the strategies themselves can interact with each other. In mountain side subsistence mode and north riverside subsistence mode, the pastoral strategies are similar, so there is no noticeable interaction between the strategies when the area of pastoral practice is changed. However, if, for example (Section 4.2; Herder, Place 11/95), river side yield-focused mode pastoralists want to shift to the mountain side subsistence mode or the north riverside subsistence mode where it is less convenient, they will not be able to maximize the benefits. Conversely, use of the land will exceed its environmental carrying capacity due to the influx of people and livestock into already densely populated areas, and the strategy will not be viable. Regarding the side job mode, pastoralists must create new opportunities for work. Consequently, the mountain side subsistence mode and the north riverside subsistence mode of the river would be the beneficiaries of the riverside yield-focused mode. As development plans progress, along with socio-economic changes, infrastructure, such as bridges, motorized wells, and roads will be put in place, reducing inconvenience. This could alleviate the densification of summer camps in river side yield-focused mode. Thus, pastoralists who desire a yield-focused mode may shift from a subsistence mode to a yield-focused mode. The reverse is also true, and once information and communication facilities are in place, a shift from a yield-focused mode to a subsistence mode, and a return to rural areas, may occur. Thus, over time, pastoralist strategies are likely to be transformed.

In this study, we considered the actual conditions of commons based on shared land use during the summer from the viewpoint of livestock practices and the livelihood strategies of the local people. Similar patterns for seasonal migration (see Figure 4) have been reported in the Bulgan Province in northern Mongolia and Arkhangai Province in the west [46,47]. It can be said that these patterns of migration implicitly establish rules, such as who uses which pastures. Therefore, a single household could manage livestock farming autonomously without consulting neighboring herders (Table 3). That livestock is accustomed to the land in daily grazing management and that herders rarely intervene in the movement of livestock contribute to reducing herder labor. In other words, except for unexpected situations, such as natural disasters, place attachment and autochthony cause patternization of movement routes, and presently, this brings stability to pastoral practices and livelihood strategies. However, as times change, the local commons will gradually reshape itself.

\subsection{Difficulties in Resource Management Observed in Local Commons}

In Altanbulag soum, migration patterns were fixed by following the land use and herding strategies of the previous generation. Further, because this method reduced herder labor, pastoral management by a single household became common. As mentioned above, these customs have the positive effect of stabilizing the livelihood of pastoralists but also have the negative effect of restricting mobility, resource use flexibility, and conventional social organization.

In Altanbulag, the grazing pastures on the south side of the river are ideal places for pastoralists, and many of them are raising herds there. However, if permission is not granted, summer camps are established on marginal pastures that have generally low utilization (Figure 7). Originally, the herders exchanged information about when and where other households would move before selecting a campsite, and the campsites did not overlap. Even if they overlapped, herders moved by making mutual concessions [48]. However, migrants are the targets of exclusion, as pastoralists stake claim and stick to places of convenience and attachment, which leads to inequalities in resource distribution among strata created by socio-cultural factors. However, there are migrants who can graze livestock on the south side of the river. One such herder was able to get the place he wanted because he knew the bugh head. Such vertical networks, except for municipalities and governments, are dominated by hierarchy and exploitation, thus, solidarity, trust, and cooperation cannot be achieved in a community [49]. Hierarchical and vertical relationships that involve unequal power relationships have strong exclusivity and tend to involve negative externalities. In other words, the exclusive environment for maintaining 
pasture conditions, which is created by indigenous nature and place attachment, causes internal stratification, and fosters resource inequality. Resource management based on the local commons exhibits both the positive and negative aspects of the elements included in the local commons itself and may cause regional disruption and decline.

\section{Conclusions}

In this study, the actual conditions of local commons were examined using the case of Mongolia while clarifying the land use and herding strategy of the local society. For this purpose, we first focused on land use and people's relationships during summer, such as summer camp selection, grazing practice, and migrant acceptance.

Excluding the ecological/geographical elements of the "surrounding natural environment" that are still inherited as traditional ecological knowledge, this study suggests that summer camp location was decided based on four new elements: "attachment to the place," "territorial bonding," "convenient environment," and "safety of winter camps." When categorized based on these living environment indicators and land use, it became clear that four types of herding strategies were established within Altanbulag soum. These determinants of summer camp and herding strategies may not be able to describe all herder behaviors, values, and practices, but they represent an important step in interpreting the local commons.

In the Altanbulag soum, place attachment created patterns of migration routes, bringing stability to pastoral practice and livelihood strategies. However, as times change, the local commons will gradually reshape itself.

On the other hand, the negative aspects of the local commons contributed to resource inequality. In other words, the objectives that individual pastoralists emphasize—such as "yield-focused mode" vs. "subsistence mode," and "surrounding environments" vs. "convenient environment"—will influence whether the outcome will be sustainable resource utilization or decline (weak ties, widening disparities, resource inequality, and resource devastation).

There may be a gap between the CBNRM currently promoted by international organizations in Mongolia and the actual practice observed in the local commons. This is because small-scale pastoral management by individual households has become the norm and pastoralists do not want to cooperate, as seen in this case study. This field survey revealed a glimpse of individualization in the herders' use of local commons. However, as the actual situation of the local commons discussed in this study focused on natural resources and the interaction of the people who communally use them, ambiguity is the norm. Therefore, it was not possible to discuss concrete numerical values in evaluating whether the local commons developed or declined within the region. Further research is needed on the assessment of local commons and the differences between CBNRM and local commons. Finally, this study can be applied as a new method for accumulating basic knowledge in the development of communal land management as well as the transformation of pastoral systems in areas with local common use systems.

Author Contributions: C.O. was the originator of the manuscript's concept and undertook data collection, analysis, and writing. M.I. provided technical guidance on research methodologies and the general structuring of the manuscript. Both authors read, corrected, and approved the final manuscript. All authors have read and agreed to the published version of the manuscript.

Funding: This research was funded by Heiwa nakajima foundation (2013-2015) and The global center of excellence for integrated field environmental science program at Hokkaido university in Sapporo, Japan.

Acknowledgments: We thank all the fellows of the GIS Section Permafrost Section, Institute of Geography and Geo-ecology, Mongolian Academy of Science, who assisted in this study. We also thank Badarch Sergelen for his support and assistance during our fieldwork. We thank Saruulzaya Adiya for GIS help.

Conflicts of Interest: The authors declare no conflict of interest. 


\section{References}

1. Hardin, G. The tragedy of the commons. The population problem has no technical solution; it requires a fundamental extension in morality. Science 1968, 62, 1243-1249.

2. Hess, C.; Ostrom, E. Understanding Knowledge as Commons: From Theory to Practice; MIT Press: Cambridge, MA, USA, 2007; pp. 4-5.

3. McCloskey, D.N. The persistence of English common fields. In European Peasants and Their Markets: Essays in Agrarian Economic History; Parker, W.N., Jones, E.L., Eds.; Princeton University: Princeton, NJ, USA, 1975; pp. 73-110.

4. Estellie, S.M. The Triage of the Commons. Presented at the Annual Meeting of the Society for Applied Anthropology, Toronto, ON, Canada, 14-18 March 1984.

5. Rose, C.M. The comedy of the commons: Custom, commerce, and inherently public property. Univ. Chic. Law Rev. 1986, 53, 711. [CrossRef]

6. NRC. The Drama of the Commons: Committee on the Human Dimensions of Global Change. In Division of Behavioral and Social Sciences and Education; Ostrom, E., Dietz, T., Dolsak, N., Stern, P.C., Stonich, S., Weber, E.U., Eds.; National Research Council, National Academies Press: Washington, DC, USA, 2002.

7. Acheson, J.M. The lobster fiefs revisited-Economic and ecological effects of territoriality in Maine lobster fishing. In The Question of the Commons. The Culture and Ecology of Communal Resources; Acheson, J.M., McCay, B.J., Eds.; University of Arizona Press: Tucson, AZ, USA, 1987; pp. 37-65.

8. McCay, B.J. A Fishermen's Cooperative, Limited: Indigenous Resource Management in a Complex Society. Anthr. Q 1980, 55, 29-38. [CrossRef]

9. McCay, B.J. Optimal foragers or political actors? Ecological analyses of a New Jersey fishery. Am. Ethnol 1981, 8, 358-382. [CrossRef]

10. Berkes, F. Sacred Ecology: Traditional Ecological Knowledge and Resource Management; Taylor \& Francis: Philadelphia, PA, USA, 1999.

11. Ostrom, E. Governing the Commons: The Evolution of Institutions for Collective Action; Cambridge University Press: Cambridge, UK, 1990; p. 271.

12. Baland, J.M.; Platteau, J.P. Halting Degradation of Natural Resources: Is there a Role and Rural Communities? Clarendon Press: Oxford, UK, 1996; p. 448.

13. Ostrom, E.; Schlager, E. The formation of property rights. In Rights to Nature: Ecological, Economics, Cultural, and Political Principles of Institutions for the Environment; Hanna, S.S., Folke, C., Maler, K., Eds.; Island Press: Washington, DC, USA, 1996; pp. 127-156.

14. Ensminger, J. Culture and property rights. In Rights to Nature: Ecological, Economics, Cultural, and Political Principles of Institutions for the Environment; Hanna, S.S., Folke, C., Maler, K., Eds.; Island Press: Washington, DC, USA, 1996; pp. 179-203.

15. Sakamoto, G.; Takiguchi, R.; Ohnuma, S. An Environmental Psychological Study about Resource Management System of Pastoral Society in Mongolia: Boundaries over Commons and Social Identity. Jpn. J. Environ. Psychol. 2015, 3, 1-10.

16. Kellert, S.R.; Mehta, J.N.; Ebbin, S.A.; Lichtenfeld, L.L. Promise, Rhetoric, and Reality Community Natural Resource Management: Promise, Rhetoric, and Reality. Soc. Nat. Resour. 2000, 13, 705-715.

17. Kumar, C. Revisiting "community" in community-based natural resource management. Community Dev. J. 2005, 4, 275-285. [CrossRef]

18. Measham, T.G.; Lumbasai, J.A. Success factors for Community-Based Natural Resources Management (CBNRM) Lessons from Kenya and Australia. Environ. Manag. 2013, 52, 649-659. [CrossRef]

19. Johnston, R.J. Spatial patterns in suburban evaluations. Environ. Plan. A 1973, 5, 385-395. [CrossRef]

20. Yamaguchi, N. Structure and spatial variation of inhabitants' evaluation of living environment in a local midsize city. Stud. Reg. Sci. 1991, 21, 149-173. [CrossRef]

21. Tanaka, G. Spatial structure of inhabitants' evaluation of residential environment in Tsuchiura city. Kikan Chirigaku 1997, 9, 137-150. [CrossRef]

22. Takashi, N. Factors Determining Young Adults' Selection of Residential Area: Influence of Demographic and Family Factors. Policy Sci. 2012, 19, 403-424.

23. Fernández-Giménez, M.E. The role of Mongolian nomadic pastoralists' ecological knowledge in rangeland management. Ecol. Appl. 2000, 10, 1318-1326. [CrossRef] 
24. Sneath, D. Mongolia in the "age of market": Pastoral Land-use and the development discourse. In Markets and Moralities: Ethnographies of Post Socialism; Humphrey, C., Mandel, R., Eds.; Berg: Oxford, UK, 2002; pp. 191-210.

25. Fernández-Giménez, M.E. Reconsidering the role of absentee herd owners: A view from Mongolia. Hum. Ecol. 1999, 27, 1-27. [CrossRef]

26. Fernández-Giménez, M.E. Spatial and social boundaries and the paradox of pastoral land tenure. Hum. Ecol. 2002, 30, 49-78. [CrossRef]

27. Humphrey, C.; David, S.; Sneath, D.A. The End of Nomadism? Society, State and the Environment in Inner Asia; Duke University Press: Durham, NC, USA, 1999; p. 368.

28. Fernández-Giménez, M.E.; Le Febre, S. Mobility in pastoral systems: Dynamic flux or downward trend? Int. J. Sust. Dev. World 2006, 13, 341-362. [CrossRef]

29. Putnam, R. The Prosperous Community: Social capital and public life. Am. Prospect. 1993, 13, $35-42$.

30. Putnam, R.D. Bowling alone: America's declining social capital. In Culture and Politics; Palgrave Macmillan: New York, NY, USA, 2000; pp. 223-234.

31. Serageldin, I.; Dasgupta, P. Social Capital: A Multifaceted Perspective; The World Bank: Washington, DC, USA, 2001; p. 440.

32. Sneath, D. Land use, the environment and development in post-socialist Mongolia. Oxf. Dev. Stud. 2003, 31, 441-459. [CrossRef]

33. Bedunah, D.J.; Schmidt, S.M. Pastoralism and protected area management in Mongolia's Gobi Gurvansaikhan National Park. Dev. Chang. 2004, 35, 167-191. [CrossRef]

34. Mearns, R. Decentralisation, rural livelihoods and pasture-land management in post-socialist Mongolia. Eur. J. Dev. Res. 2004, 16, 133-152. [CrossRef]

35. Kamimura, A. Pastureland Use in Pastoralism in Post-Socialists in Mongolia. Available online: http://www.tufs. ac.jp/ts/personal/kamimura/docs/pastureland_use_in_Mongolia.pdf (accessed on 21 June 2020). (In Japanese).

36. Fernández-Giménez, M.E.; Batbuyan, B. Law and Disorder: Local Implementation of Mongolia's Land Law. In Proceedings of the 8th Biennial Conference of the International Association for the Study of Common Property, Bloomington, IN, USA, 30 May-4 June 2000.

37. Baival, B.; Fernández-Giménez, M.E. Meaningful learning for resilience-building among Mongolian pastoralists. Nomad People 2012, 16, 53-77. [CrossRef]

38. Ulambayar, T.; Fernández-Giménez, M.E.; Baival, B.; Batjav, B. Social Outcomes of Community-based Rangeland Management in Mongolian Steppe Ecosystems. Conserv. Lett. 2017, 10, 317-327. [CrossRef]

39. Fernández-Giménez, M.E.; Batkhishig, B.; Batbuyan, B.; Ulambayar, T. Lessons from the Dzud: Community-based rangeland management increases the adaptive capacity of Mongolian herders to winter disasters. World Dev. 2015, 56, 48-65. [CrossRef]

40. Addison, J.; Davies, J.; Friedel, M.; Brown, C. Do pasture user groups lead to improved rangeland condition in the Mongolian Gobi Desert? J. Arid Environ. 2013, 94, 37-46. [CrossRef]

41. Tshukihara, T. A study on the types and transitions of mobile pastoralism. Stud. Humanit. 2000, 52, 47-71. (In Japanese)

42. Dorligsuren, D.; Batbuyan, B.; Densambu, B.; Fassnacht, S.R. 9 Lessons from a community development approach in Mongolia: Ikhtamir pasture user groups. In Restoring Community Connections to the Land; Fernández-Giménez, M.E., Wang, X., Baival, B., Eds.; CABI: Wallingford, Oxford, UK, 2011; p. 166.

43. Minato, K. Economics of Nomadic Pastoralism another "Agricultural Sector" in Mongolian Pastoral Area; Koyoshobo: Japan, 2017; p. 184. (In Japanese)

44. Hirata, M.; Kaihotsu, I.; Batmunkh, D.; Toukura, Y.; Hongo, A. Migration system in Dondgobi Province, Mongolia. J. Arid Land Stud. 2005, 15, 139-149. (In Japanese)

45. Sneath, D. Spatial Mobility and Inner Asian Pastoralism. In The End of Nomadism? Humphrey, C., Sneath, D., Eds.; Duke University Press: Durham, NC, USA, 1999; p. 368.

46. Ozaki, T. Study on diversity and transformation of herding strategies in Mongolian Pastoral Society. Ph.D. Thesis, Tohoku University, Sendai, Japan, 2017. (In Japanese).

47. Kazato, M. The flexibility of pastoralists' social groupings and the difficulty of herding: Labor organization and herd control for day-trip herding of sheep and goats in Arkhangai Province, Mongolia. Afr. Asian Stud. 2006, 6, 1-43. 
48. Imaoka, R. Transformation of Nomadic Pastoralism Society in Mongolia: From the Perspective of Recourse Conflict Prevention; IPSHU Research Report Series; Part 7; IPSHU: Hiroshima, Japan, 2005; p. 71. (In Japanese)

49. Levi, M. Social and unsocial capital: A review essay of Robert Putnam's Making Democracy Work. Politics Soc. 1996, 24, 45-55. [CrossRef]

Publisher's Note: MDPI stays neutral with regard to jurisdictional claims in published maps and institutional affiliations.

(C) 2020 by the authors. Licensee MDPI, Basel, Switzerland. This article is an open access article distributed under the terms and conditions of the Creative Commons Attribution (CC BY) license (http://creativecommons.org/licenses/by/4.0/). 